\title{
Family Business/Entrepreneurial Studies: A Small Private Liberal Arts College Approach
}

M. Tony Bledsoe, (E-mail: bledsoem@meredith.edu), Meredith College

\begin{abstract}
The Center for Women's Business Research reports that, "As of 2002, there are an estimated 10.1 million privately-held majority or 50\% women-owned businesses in the U.S., accounting for $46 \%$ of all privately-held firms. These firms generate $\$ 2.3$ trillion in sales and employ 18.2 million workers." Further it states, "In North Carolina, women-owned firms approach 171,000, employment tops 307,000, and sales exceed \$37.3 billion." Given the impact of these statistics, the questions arises what, if anything, should a small, all-female, undergraduate, private liberal arts college do about developing and implementing a Family Business/Entrepreneurial (FB/E) studies program? This paper reviews issues: national, state and college to determine the direction for establishing a program at this school.
\end{abstract}

\section{INTRODUCTION}

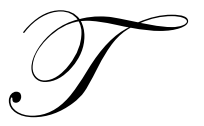

hrough enterprise women in the USA are becoming an increasing economic force. This change brings with it a number of challenges for society in general and for certain organizations specifically. One distinct group is academic institutions having a vested interest in offering educational opportunities for women who have a need or interest in family business and entrepreneurship studies. Within colleges and universities, factors such as teaching, researching and serving are ever present. For smaller schools with limited human and non-human resources this is a constant constraint. Certainly those anticipating adding additional programs face a struggle in attempting to reconcile and balance these three elements.

The purpose of this paper is to describe how one small college addresses the issues of developing the rationale and designing a plan for implementing a Family Businesses/Entrepreneurship studies program. The ongoing process includes the following elements: college setting, program rationale, program model and recommendations for further study.

\section{COLLEGE SETTING}

Meredith College, located in Raleigh, North Carolina, is devoted to offering educational opportunities for women. It is the largest women's college in the southeast United States and is very near the Research Triangle Park. This is one of the major research centers in the USA. The college has a full complement of teaching, researching and performing venues including a state-of-the-art science and mathematics facility. There are some 2600 students in its undergraduate program. The college has a mission statement promoting global awareness, ethical inquiry, creative thoughts, innovation, civic engagement and leadership (Meredith College, 2003). It has a strong tradition of liberal arts education that is comprehensive and focuses on preparing women for leadership and service. The college is nationally recognized for strength in humanities and arts with $25 \%$ of its students seeking degrees in business (Meredith College, 2002). 


\section{PROGRAM RATIONALE}

Colleges and universities contemplating some form of Family Business/Entrepreneurial initiative should consider the impact of how this fits with the mission, needs/wants of students and service to those with a vested interest (stakeholders). The decision at Meredith College was influenced by national, state and college level factors supported by statistical evidence and empirical research. National level facts show "As of 2002, there are an estimated 10.1 million privately-held majority or 50\% women-owned businesses in the U.S., accounting for $46 \%$ of all privately held firms" (Center for Women's Business Research, 2003). "In North Carolina", home state for Meredith College, figures show "women-owned firm's approach 171,000, employment tops 307,000 and sales exceed \$ 37.3 billion" (Center for Women's Business Research, 2001, p.1). Research conducted at Meredith College reveals a significant segment of students coming from families that own businesses and expressing an interest in taking Family Business/Entrepreneurial courses (Bledsoe \& Richardson, 2002). This indicates the possibility for the establishment of a minor in this field. This information led to the development of a plan directed toward program implementation. The program process included developing a model that meshed with the Meredith College mission and academic needs.

\section{MODEL DEVELOPMENT}

Events leading to developing the Meredith College Family Business/Entrepreneurial Studies model began in December 2001. A senior Business Administration major requiring an extra three credit hours to graduate in May 2003 requested and was granted an independent study course. One of the key elements of that course was data collection. That required selecting a survey instrument and identifying a student population from which to collect desired information. The survey chosen was first developed and implemented by Greg McCann and Dr. Michelle DeMoss at Stetson University in Deland, Florida (Attachment A). Students surveyed were business majors and minors. The results of this early survey revealed that $29.5 \%$ of the students surveyed came from families owning a business and that many students were interested in Family Business/Entrepreneurial studies (Bledsoe \& Richardson, 2002). This research was then followed by a survey of all fall freshmen of 2002 (Bledsoe \& Hege, 2002) and fall freshman 2003 (Bledsoe \& Butler, 2003). These surveys showed similar results; namely an interest in a FB/E student program.

Establishing a rationale, identifying student interests and gaining institutional support provide the momentum for developing a model suitable for a given college or university. Within this process it is important, in planning and establishing a model, that the needs of various internal and external stakeholders be considered. This also means setting a direction that is compatible with the mission of the institution.

What direction to take? Two major factors impacting this decision were the available human and nonhuman resources. Two approaches considered were development of a center or establishment of a forum. A direction differing from these two was taken at Stetson. There a "holistic" (Attachment B) approach was implemented. After careful examination it was decided that a program approach would work best as a starting point at Meredith College. This allowed slow, steady, solid growth. It was further decided the program would include curriculum, service, research and consortium components. It needed to be student (all) centered plus family business and entrepreneur driven (Attachment C).

\section{CURRICULUM}

Introduction to the Meredith College Family Business/Entrepreneurial Studies model begins with curriculum. The curriculum component is central to the Meredith FB/E student program. The key consideration is to attempt to offer courses of study that best served the constituent student population. For Meredith that means providing academic and experiential learning opportunities. An academic FB/E minor was proposed. The minor would have 18 credit hours that include required and elective courses. The proposed required courses are: (1) Family Business Issues, (2) Entrepreneurship, (3) Research and (4) Internship. The minor would also include 6 hours of elective courses to be chosen from across disciplinary boundaries. Approval for the minor has to be navigated through the college academic procedures. Meanwhile, two important milestones have been reached. The first course, 
Family Business Issues, was offered during the spring 2004 semester. That will be followed by the Entrepreneurship course to be offered during the fall 2004 semester. The plan is to implement the Research and Internship courses within the $2005-2006$ academic year. This would complete the required courses of the minor. If approval occurs, the elective courses for this minor would then be selected.

\section{SERVICE}

Service has two pathways. One that assists student development and the other is outreach. The central idea is to blend the two when possible to attain maximum advantage. The service centerpiece for the Meredith model is to stay within the Meredith community. This amounted to an evolutionary process during which certain identities emerged. These identities are: pioneers, alumnae partners, family partners and student partners. The designation pioneers applies to any Meredith College student taking a course within the FB/E program. Alumnae partners refer to Meredith graduates who have established and/or belong to a family business. Family partners apply to Meredith College student's families that own a business while student partners recognition means students presently enrolled in the college who own a business. These groups form the nucleus for connections, affiliation and participation. Several examples of how these came together include: special events, guest speakers and partnership connections. Two "events" were scheduled and held. The first occurred on June 11, 2003 with students, faculty, staff, administration and alumnae meeting for an information and update luncheon. The second, held on March 24, 2004, focused on the relationships between alumnae partners and student "pioneers". Additional service opportunities are available through professional associations. Among these are: United States Association for Small Business and Entrepreneurship (USASBE), Family Firm Institute (FFI), Students in Free Enterprise (SIFE) and Collegiate Entrepreneurs' Organization (CEO) memberships. These organizations provide avenues for faculty as well as student development.

\section{RESEARCH}

The research component of the Meredith FB/E model focused on conducting research that would help determine student interest and support for implementing the program. As previously noted, Stetson University consented to the modification and use of its survey form (Attachment A) to gather the desired student data. It was used to collect information from three groups. They were: School of Business majors/minors spring 2002, freshman class fall 2002 and freshman class fall 2003. The survey helped to determine the amount of student interest, support and family connection in family owned businesses. This information was instrumental in the decision-making process to institute an FB/E program.

Some of the findings from the three surveys demonstrate the value of data collection to the decisionmaking process. For example, when students were asked about family business connections the positive responses ranged between a low of $24.1 \%$ and a high of $29.1 \%$. Response to the what generation question was strong with second generation high of $77.3 \%$ to a low $72.5 \%$. Interest in taking a FB/E class ranged between $23.4 \%$ and $58.5 \%$. The surveys generally showed that having an FB/E program would have had little effect on the decision to enroll at Meredith College (Bledsoe \& Richardson, 2002; Bledsoe \& Hege, 2003; Bledsoe \& Butler, 2003).

This research effort marks a modest beginning for establishing a strong database. Other research avenues will be directed towards: alumnae partner data, board composition, case studies and the continuing freshmen class surveys. As with previous research efforts, student participation will be an integral part of this process. This aligns with the direction the college is taking to emphasis faculty-student joint research projects.

\section{CONSORTIUM}

To date the majority of the Meredith College Family Business/Entrepreneurial Studies model has shown steady progress. The consortium part shows the least amount of development. Not for lack of interest but simply due to a matter of resource allocation. The consortium idea was built around the fact that four all female undergraduate schools are located in North Carolina. These schools exist within a fairly small radius of one another. Originally the thinking was to create links among the four schools so that collaboration could occur. Presently, a change to internal 
collaboration with other schools within the college setting is a more efficient use of time and effort. Changing to this direction allows for the utilization of established channels of communication and interaction. The external consortium concept has not be abandoned; only delayed while other components of the Meredith model mature.

\section{CONCLUSION/RECOMMENDATIONS}

Small institutions contemplating Family Business/Entrepreneurial Studies may first consider finding ways to measure student interest in this field of study. Next to be considered would be institutional support and the type of resources that can be committed to such a project. After this, it is important to look at the external stakeholders in an effort to determine the support that could be gained. When the decision is made to go forward, one of the key elements for early development of a program is the identification of leadership. This leader would preferably be a faculty member with a strong interest and perhaps a background in Family Business/Entrepreneurial experiences.

Any emerging field of study has basic issues to examine. This is true for FB/E venues. Some recommendations for further investigation are:

- $\quad$ Develop basic research tools to help gain academic recognition

- $\quad$ Create methods for measuring the amount of FB/E culture within an institution

- $\quad$ Form collaborative connections with other schools to strength scarce resources

- $\quad$ Establish a means for effectively communicating the goals of the FB/E processes

- $\quad$ Develop differing FB/E models

- $\quad$ Examine board structure(s)

- $\quad$ Study the role of the spouses.

Finally, it is an exciting time to be involved in FB/E studies. Colleges and universities have an opportunity to help shape the intellectual contributions and practices within this field of study. A word of caution is that many may rush to implementation in the short-term without respect to long-term consequences. Future activities for the Meredith College FB/E program include: choosing members, selecting an advisory group, expanding the alumnae partner association and gaining ongoing funding.

\section{REFERENCES}

1. Bledsoe, M.T., and E. Richardson. (2002). "Business Majors and Minors" Unpublished Family Owned Business Research, School of Business at Meredith College, Raleigh, N.C.

2. Bledsoe, M.T., and Erin Hege. (2002). "Freshman Class Fall 2002" Unpublished Family Owned Business Research, School of Business at Meredith College, Raleigh, N.C.

3. Bledsoe, M.T., and Tom Butler. (2003). "Freshman Class Fall 2003" Unpublished Family Owned Business Research, School of Business at Meredith College, Raleigh, N.C.

4. Center for Women's Business Research. (2001). "Women-Owned Businesses in North Carolina, 2002: A Fact Sheet." Women-Owned Businesses in 2002: Trends in the U.S. and 50 States. Washington, D.C.: n.p., $1-3$.

5. Center for Women's Business Research. (2003). Key Facts About Women-Owned Businesses, April. Washington, D.C.: n.p.

6. McCann, Greg. (2003). "Where Do We Go from Here? Strategic Answers for University-Based Family Business Programs.” Family Business Review, June, 16 (2), 125-144.

7. McCann, Greg, Michelle DeMoss, and Jill Perry. (2002). Personal interview, October.

8. Meredith College. (2002). A Profile. Raleigh, N.C.: Meredith College Office of Marketing and Communications, August.

9. Meredith College. (2003). Meredith College Undergraduate Catalogue. Raleigh, N.C.: n.p., 27, 11.

10. Poza, Ernesto J. (2004). Family Business. Ohio: South-Western. 


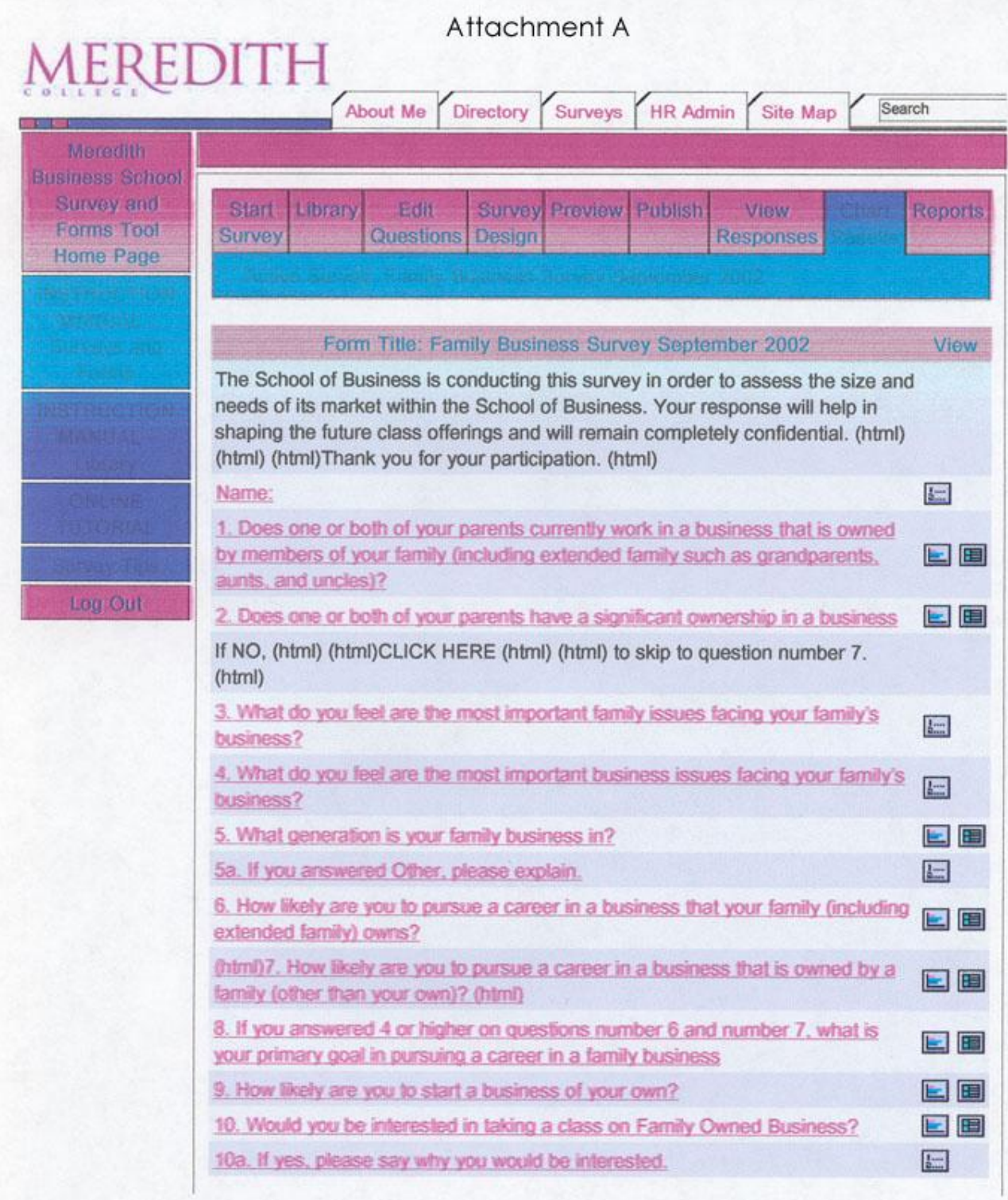




\section{Attachment A (con't.)}

Please read the following School of Business Program description below and answer the following questions on the next page. (html) (html)The School of Business will serve two groups. Externally, it will conduct retreats and other programs for family businesses. Internally, it will develop courses for undergraduates. The School of Business will offer courses for students that will help them to assess their readiness to enter a family business (FB); holistically leam about FBs (both on an experiential hands-on level with their own FB where feasible, and on an academic broad-based conceptual level); and to develop the knowledge and skill base to begin or continue their career in a FB. The undergraduate Program will also integrate the hard (e.g., finance, accounting) and soft (e.g., management, psychology) aspects of FB.

11. How likely would it be that you would enroll in a class offered by the School of Business?

12. How likely would it be that you would select a minor in Family Business if offered by the School of Business?

13. If previously you knew that School of Business offered Family Business Classes, would this have been a deciding factor for your coming to Meredith College?

13a. If yes, state why.

14. What is your maior or miner?

15. For those who have taken the Myers-Briggs Type Indicator (MBTI). Dlease check your preference for each of the four MBTI scales. (ff you don't know the MBTI, please indicale.)

15a. (E) Extravent or (i) introvert

15b. (N) Intuitive or (S) Sensing

15c. (T) Thinking or (F) Feeling

15d. (J) Judging or (P) Perceiving

For families that own or operate businesses, the School of Business is planning to offer seminars and retreats on current business issues for interested family businesses in the area. (html) (html)The School of Business would value the opportunity to let you and your parents give your input and advice on the

creation of the classes and seminars. So if your parent(s) own or are involved in a family business, please fill in the name of the person(s) and his/her address below so that we may develop the most beneficial Programming possible.

Name:

Address:

City:

State:

Zip: 
Attachment B

\section{McCann}

Appendix C: Holistic Model

Appendix C: Holistic Model
University Family Business Center
Holistic Model-Visual Model
Scbolarship:
Theme:
External Programming:
All activities for family business college students, including curriculum, peer
groups, community service, speakers, and internships
All activities for family business families, including retreats, affinity groups, and
speakers
In its broadest sense, the pursuit, development, critique, and application of
knowledge




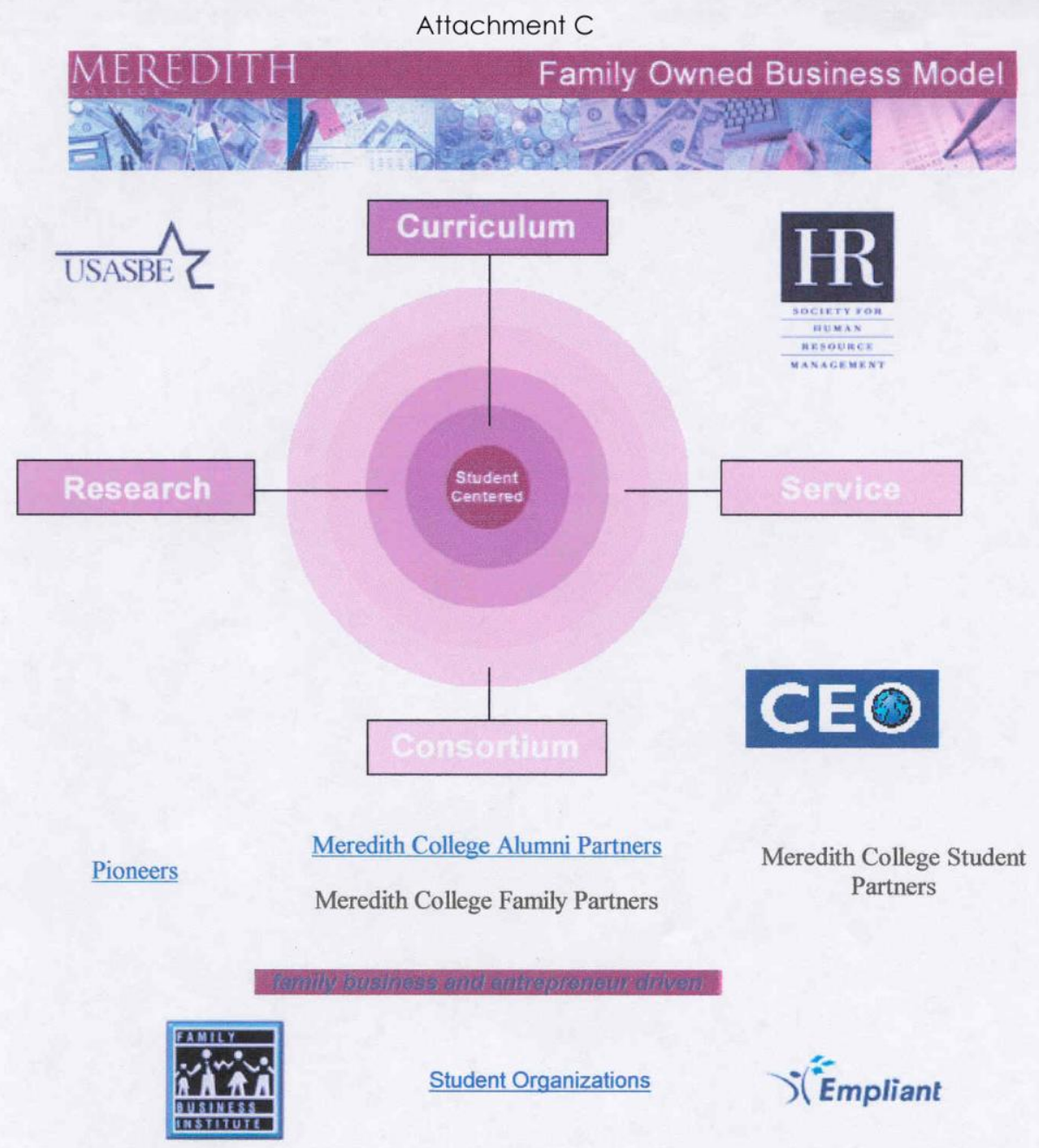

